(c) American Dairy Science Association, 2005.

\title{
Development of a System to Predict Feed Protein Flow to the Small Intestine of Cattle*
}

\author{
H. G. Bateman, II, ${ }^{1}$ J. H. Clark, ${ }^{2}$ and M. R. Murphy ${ }^{2}$ \\ ${ }^{1}$ Department of Dairy Science, Louisiana State University Agricultural Center, Baton Rouge 70803 \\ ${ }^{2}$ Department of Animal Sciences, University of Illinois, Urbana 61801
}

\begin{abstract}
A data set constructed from research trials published between 1979 and 1998 was used to derive equations to adjust published tabular values for the rumen-undegradable protein (RUP) content of feeds to better predict the passage of nonammonia nonmicrobial N (NANMN) to the small intestine of lactating dairy cows. Both linear and nonlinear forms of equations were considered for making adjustments. Iterative processes were used to estimate equation parameters. A logistic equation was developed and considered to be the most optimal for adjustment of published tabular RUP contents of feeds. The equation is a function of dietary dry matter intake (DMI) and includes terms for tabular RUP and nonprotein $\mathrm{N}$ contents of individual feeds. The equation has a standard error of prediction of $69.29 \mathrm{~g}$ of NANMN/ $\mathrm{d}$ per cow and a root mean square prediction error of $104.63 \mathrm{~g}$ of NANMN/d per cow. Independent evaluation of the equation indicated that the concept of variable RUP content for feeds based on DMI is correct. Further refinements may be needed as other data become available to quantify the effects of additional factors on the RUP value of feeds.
\end{abstract}

(Key words: protein, degradability, model, dairy cow)

Abbreviation key: $\mathbf{M C P I}=$ maintenance $\mathrm{CP}$ intake, MEI = maintenance energy intake, MPIAF = MCPI adjustment factor, MSPE = mean square prediction error, NANMN = nonammonia nonmicrobial $\mathrm{N}$, RDTP = ruminally degradable true protein, RMSPE = root mean square prediction error, SEY $=$ standard error of prediction.

\section{INTRODUCTION}

Numerous factors have been suggested to affect passage of microbial and feed protein to the small intestine

Received March 12, 2004.

Accepted September 9, 2004.

Corresponding author: H. G. Bateman, II; e-mail: hbateman@ agcenter.lsu.edu.

*Approved by the director of the Louisiana Agricultural Experiment Station as publication No. 04-24-0121. of ruminants including feed intake; forage-to-concentrate ratio in the diet; source, quality, and amount of carbohydrate and $\mathrm{CP}$ in the diet; ruminal $\mathrm{pH}$; associative effects of feeds; frequency of feeding; forage and grain processing; forage conservation methods; micronutrient supply; feeding buffers, salts, and ionophores; and environmental conditions (Clark and Davis, 1983; NRC, 1985; Sniffen and Robinson, 1987; Clark et al., 1992). Because many variables affect degradability of protein in the rumen, RUP content of a given feed is not constant in all feeding situations. The many factors that affect degradation of feed protein in the rumen currently make it impossible to predict passage of feed protein to the small intestine with sufficient accuracy.

Santos et al. (1998) reviewed published literature where protein sources considered high in RUP content replaced soybean meal and concluded that increasing the RUP content of diets fed to lactating cows does not consistently improve lactational performance. Santos et al. (1998) also indicated that this may have resulted from 1) decreased microbial CP synthesis in the rumen, 2) poor AA profile of RUP, 3) low intestinal digestibility of RUP, or 4) the RUP content of control diets being adequate to maximize lactational performance. Bateman et al. (2001a) reported that prediction models underestimated the mean passage of feed $\mathrm{CP}$ to the small intestine of dairy cows. The underestimation of feed protein passage to the small intestine of dairy cows eating large amounts of feed was attributed to an overestimation of degradability of individual feed proteins.

Clark et al. (1992) reported a linear relationship between OM intake and passage of nonammonia nonmicrobial N (NANMN) to the small intestine of dairy cows. Santos et al. (1998) reported that there were no differences in DM or N intakes when soybean meal was replaced by protein sources reported to be high in RUP content. Therefore, it is likely that the RUP content of feeds increases as DMI increases.

The objectives of this work were 1) to evaluate some tabular values for the RUP content of feeds (NRC, 1985, $1989,1996)$ for their ability to predict feed protein flow to the small intestine of lactating dairy cows and 2) to develop an equation that could be used to modify 
tabulated RUP values to better predict feed protein flow to the small intestine of lactating dairy cows.

\section{MATERIALS AND METHODS}

\section{Model Development}

A data set was constructed from research trials published between 1979 and 1998 (Appendix Table 1). The data set consisted of 150 treatment means from 35 research papers. The data set was supplemented with 8 treatment means from 2 unpublished trials from the University of Illinois. All were Latin square designs that measured passage of total, microbial, and NANMN to the small intestine of cattle. All trials were conducted using duodenally cannulated cattle. All treatment means were assumed to have been measured without bias, which might or might not have been correct.

Dry matter intake was reported in all studies. Diet composition was either reported or could be calculated for all studies. When CP content of individual feeds was reported, those values were used to calculate $\mathrm{CP}$ intake; otherwise, values in Table 1 were used to calculate CP intake. The CP compositions of feeds in Table 1 are those reported by NRC (2001). The NPN values (Table 1 ) were supplied by W. Weiss (personal communication, 1998) and represent a compilation of data from commercial laboratories, literature data, Nutrient Requirements of Beef Cattle (NRC, 1996), and unpublished data provided by university researchers. Tabulated values for RUP were from published sources (NRC, 1985, 1989, 1996). When published values conflicted for feeds, the more recent value was used for further analysis. Published RUP values were supplemented with data compiled from literature when feeds were encountered that had no published values. Tabulated values for forages were grouped in ways similar to those in the dairy NRC (2001). The RUP intake was calculated by multiplying $\mathrm{CP}$ intake from each $\mathrm{N}$-containing feed in the diet by the RUP percentage of that feed and then summing intakes of RUP from all feeds in a diet. The calculated RUP intake was assumed to be equal to passage of RUP to the small intestine and was compared with passage of NANMN to the small intestine after dividing estimated passage of RUP by 6.25 .

Two forms of equations (linear and nonlinear) were developed to adjust RUP values of individual feeds as a function of DMI. To develop these equations, maintenance energy intake (MEI) for lactating cows was set equal to $6 \mathrm{~kg}$ of $\mathrm{DM} / \mathrm{d}$, and maintenance $\mathrm{CP}$ intake (MCPI) was set equal to $2.5 \mathrm{~kg}$ of DM/d when the DMI contained $1.72 \mathrm{Mcal}$ of $\mathrm{NE}_{\mathrm{L}} / \mathrm{kg}$ and $17 \% \mathrm{CP}$. These quantities of DM were adequate to supply the energy and protein for maintenance of a $650-\mathrm{kg}$ cow (NRC, 1989).
Equations were developed that adjusted published RUP values (Table 1) to maximize the coefficient of multiple determination when the observed passage of NANMN was regressed against the predicted passage of NANMN. Equations were parameratized by an iterative process using the solver in Microsoft Excel 2002. After providing initial estimates for coefficients in all equations based on a visual estimation from plots of measured and predicted passage of RUP, iterations were conducted to maximize the coefficient of multiple determination $\left(\mathrm{R}^{2}\right)$. Iterations were constrained by forcing the slope to equal unity while the intercept equaled zero for the prediction line. Equations were considered to adequately adjust RUP values when the slope of the regression of predicted and measured values did not differ from unity, and the intercept of this regression did not differ from zero (Graybill and Iyer, 1994). All regression lines were considered significant when a Student's $t$-test indicated that their slope differed from zero with a probability of $P<0.05$. Bias in prediction was determined when the slope of the regression line between the prediction residuals (measured - predicted values) and the predicted values differed from zero with a probability of $P<0.05$.

\section{Model Evaluation}

A second data set was constructed from research trials published between 1998 and 2003 (Appendix Table 2). These data represented 52 treatment means from 12 research papers that were from trials similar to those used for model development. The data set was supplemented with 4 treatment means from one unpublished trial from the University of Illinois. Again, all treatment means were assumed to have been measured without bias, which might or might not have been correct.

Dry matter intake and diet composition were either available for all trials or could be calculated. When CP contents of feeds were reported, those values were used to calculate CP intake; otherwise, values in Table 1 were used to calculate CP intake. The NPN values were from Table 1. Tabulated values for RUP contents of feeds were from Table 1 . The calculations used for estimating flow of RUP were similar to those used in model development. The calculated RUP intake was assumed to equal the passage of RUP to the duodenum and was compared with passage of NANMN to the duodenum after dividing estimated passage of RUP by 6.25 .

A 2-tailed Student's $t$-test was used to compare mean predicted and measured passage of NANMN to the duodenum (Snedecor and Cochran, 1989). Subtracting the predicted passage of NANMN from the measured passage of NANMN generated residuals of prediction for the individual observations. These residuals were sta- 
Table 1. The CP, NPN, and tabulated RUP content of selected feedstuffs.

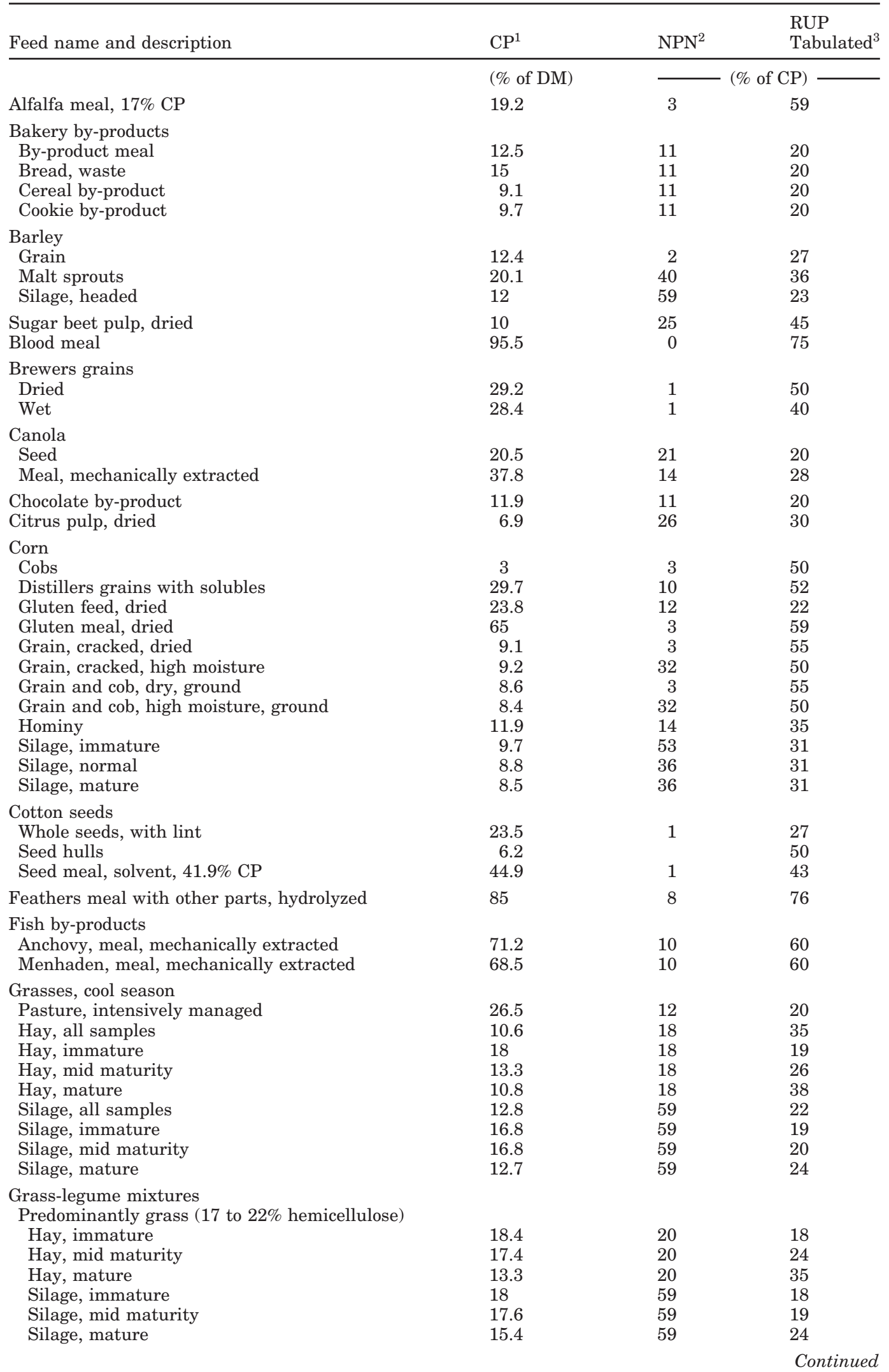


Table 1 (Continued). The CP, NPN, and tabulated RUP content of selected feedstuffs.

\begin{tabular}{|c|c|c|c|}
\hline Feed name and description & $\mathrm{CP}^{1}$ & $\mathrm{NPN}^{2}$ & $\begin{array}{l}\text { RUP } \\
\text { Tabulated }^{3}\end{array}$ \\
\hline & $(\%$ of $\mathrm{DM})$ & $\longrightarrow$ & CP) \\
\hline \multicolumn{4}{|c|}{ Mixed grass and legume (12 to $15 \%$ hemicellulose) } \\
\hline Hay, immature & 19.7 & 22 & 17 \\
\hline Hay, mid maturity & 18.4 & 22 & 22 \\
\hline Hay, mature & 18.2 & 22 & 33 \\
\hline Silage, immature & 20.3 & 60 & 17 \\
\hline Silage, mid maturity & 19.1 & 60 & 19 \\
\hline Silage, mature & 17.4 & 60 & 24 \\
\hline \multicolumn{4}{|c|}{ Predominantly legume (10 to $13.5 \%$ hemicellulose) } \\
\hline Hay, immature & 20.5 & 24 & 17 \\
\hline Hay, mid maturity & 19.1 & 24 & 21 \\
\hline Hay, mature & 17.2 & 24 & 31 \\
\hline Silage, immature & 20 & 60 & 17 \\
\hline Silage, mid maturity & 19 & 60 & 19 \\
\hline Silage, mature & 18.3 & 60 & 23 \\
\hline \multicolumn{4}{|l|}{ Legumes, forage } \\
\hline Pasture, intensively managed & 26.5 & 15 & 13 \\
\hline Hay, all samples & 20.2 & 27 & 19 \\
\hline Hay, immature & 22.8 & 27 & 16 \\
\hline Hay, mid maturity & 20.8 & 27 & 19 \\
\hline Hay, mature & 17.8 & 27 & 28 \\
\hline Silage, all samples & 20 & 60 & 23 \\
\hline Silage, immature & 23.2 & 60 & 16 \\
\hline Silage, mid maturity & 21.8 & 60 & 18 \\
\hline Silage, mature & 20.3 & 60 & 23 \\
\hline Linseed meal, solvent & 32.6 & 5 & 23 \\
\hline \multicolumn{4}{|l|}{ Meat } \\
\hline Meal, rendered & 57.6 & 3 & 56 \\
\hline Meat and bone, rendered & 54.2 & 3 & 56 \\
\hline \multicolumn{4}{|l|}{ Molasses } \\
\hline Beet sugar & 8.5 & & 20 \\
\hline Sugarcane & 5.8 & & 20 \\
\hline \multicolumn{4}{|l|}{ Oats } \\
\hline Grain, rolled & 13.2 & 1 & 17 \\
\hline Hay, headed & 9.1 & 27 & 20 \\
\hline Silage, headed & 12.9 & 55 & 23 \\
\hline Peanut meal, solvent & 51.8 & 2 & 30 \\
\hline Rice bran & 15.5 & & 25 \\
\hline \multicolumn{4}{|l|}{ Sorghum } \\
\hline Grain, dry rolled & 11.6 & 4 & 57 \\
\hline Silage & 9.1 & 27 & 29 \\
\hline \multicolumn{4}{|l|}{ Soybean } \\
\hline Hulls & 13.9 & 13 & 25 \\
\hline Meal, expellers, $45 \% \mathrm{CP}$ & 46.3 & 5 & 47 \\
\hline Meal, solvent, $44 \% \mathrm{CP}$ & 49.9 & 3 & 35 \\
\hline Meal, solvent, $48 \% \mathrm{CP}$ & 53.8 & 3 & 35 \\
\hline Seeds, whole & 39.2 & 25 & 26 \\
\hline Seeds, whole roasted & 43 & 25 & 62 \\
\hline Silage, early maturity & 17.4 & 60 & 23 \\
\hline Sunflower meal, solvent & 28.4 & 3 & 26 \\
\hline Tomato pomace & 19.3 & 7 & 62 \\
\hline \multicolumn{4}{|l|}{ Wheat } \\
\hline Bran & 17.3 & 2 & 20 \\
\hline Grain & 14.2 & 2 & 23 \\
\hline Hay, headed & 9.4 & 45 & 23 \\
\hline Middlings & 18.5 & 2 & 21 \\
\hline Silage, early head & 12 & 64 & 20 \\
\hline Straw & 4.8 & & 40 \\
\hline
\end{tabular}

${ }^{1}$ Adapted from NRC (2001).

${ }^{2}$ Supplied by W. Weiss (personal communication, 1998).

${ }^{3}$ Derived from NRC (1985, 1989, and 1996) and supplemented with literature data. 
Table 2. Mean, maximum, minimum, and standard error of the mean for DMI, $\mathrm{N}$ intake, and measured flow of nonammonia nonmicrobial N (NANMN) to the small intestine from published data. ${ }^{1}$

\begin{tabular}{lcccc}
\hline & Mean & SE & Minimum & Maximum \\
\hline DMI, kg/d & 17 & 0.45 & 3 & 27 \\
N intake, g/d & 470 & 14 & 80 & 855 \\
NANMN, g/d & 217 & 10 & 16 & 465 \\
\hline
\end{tabular}

${ }^{1}$ Derived from research papers cited in Appendix Table 1.

tistically analyzed using the mean square prediction error (MSPE) according to procedures outlined by Theil (1966). This analysis allows the MSPE to be subdivided into proportions of 1 ) error of predicting the mean (mean bias); 2) systematic errors in the prediction function, which can be corrected through a linear adjustment (slope bias); and 3) error in prediction because of random variance around the line of perfect prediction (dispersion). Mean bias was calculated as (mean predicted - mean observed $)^{2}$. Slope bias was calculated as $R^{2}$ for regression of predicted and observed values $\times(\mathrm{MSPE}$ - mean bias). Dispersion was calculated as MSPE mean bias - slope bias.

\section{RESULTS AND DISCUSSION}

A summary of the univariate statistics for the data set used to develop the equations is shown in Table 2. A wide range of diets and DMI were included in the data set (see references in Appendix Table 1).

The relationship between predicted passage of NANMN using tabulated values for the RUP contents of feeds and measured passage of NANMN to the duodenum from the data set is presented in Figure 1. There

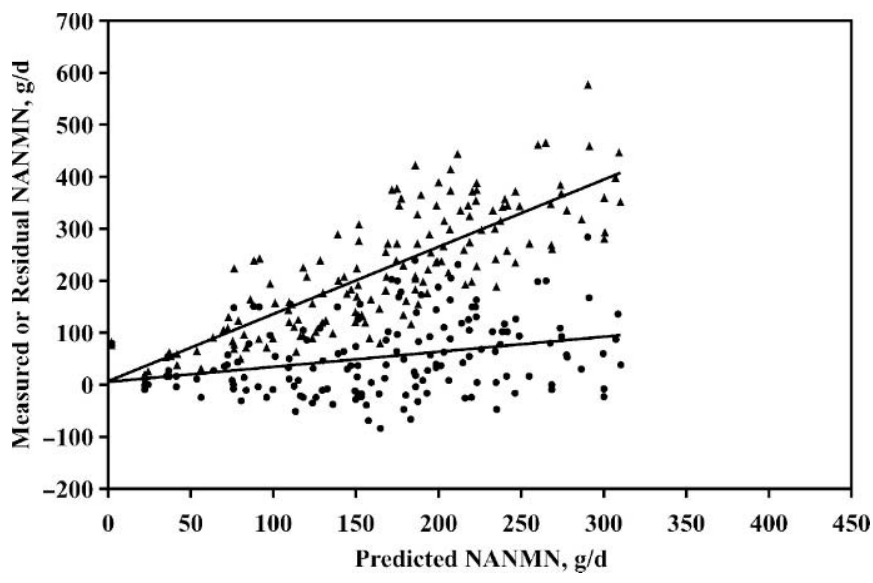

Figure 1. Relationship between measured $(\mathbf{\Delta})$ or residual ( (measured - predicted) passage of nonammonia nonmicrobial $\mathrm{N}$ (NANMN) and predicted NANMN at the duodenum of dairy cows using tabular values for the RUP content of feeds to predict the passage of NANMN. Measured NANMN $=1.29 \pm 0.074 \times$ predicted NANMN $+6.78 \pm 13.36(P<0.01) ; R^{2}=0.6605 ;$ root mean square prediction error $=89.34 \mathrm{~g}$ of NANMN/d. Residual NANMN $=0.287$ $\pm 0.074 \times$ predicted NANMN $+6.93 \pm 13.36(P<0.01) ; R^{2}=0.0879$. was a positive linear relationship between measured and predicted passage of NANMN to the duodenum. Furthermore, a linear bias was indicated by the regression of residuals (measured - predicted) for NANMN and predicted passage of NANMN to the duodenum. Using tabular values to predict flow of NANMN at the small intestine produced a root mean square prediction error (RMSPE) of $89.34 \mathrm{~g}$ of NANMN/d (Theil, 1966) and a standard error of prediction (SEY) of $43.07 \mathrm{~g}$ of NANMN/d. Distribution of the errors contained in the MSPE analysis is presented in Table 3. These data indicate that tabulated values for the RUP contents of feeds did not accurately predict the measured passage of RUP to the duodenum of cattle and are in agreement with previous evaluations from our laboratory (Bateman et al., 2001a,b).

Tyrrell and Moe (1975) reported that the digestibility of a specific feed is not constant but changes with intake. An approximate 4 percentage unit decrease in total digestible nutrient content of a diet has been reported for each multiple that energy intake increases above that required for maintenance (Moe and Tyrrell, 1976). This reduction in total digestible nutrient content of a diet is a result of the depression in the digestibility of the diet as energy intake (and presumably DMI) increases. It is unlikely that the entire depression of digestibility occurs postruminally without any depression of ruminal fermentation. If ruminal fermentation was depressed, a larger percentage of the CP from the feed would pass intact to the small intestine. Therefore, an equation (not shown) was developed to apply a 4 percentage unit decrease in ruminal degradability of protein for each multiple increase in MEI above maintenance to all feeds, and the relationship between predicted and measured passage of NANMN to the duodenum of cows in the data set were compared. Dry matter intake for maintenance was set to $6 \mathrm{~kg} / \mathrm{d}$ for this analysis and was based on a dietary energy content of $1.72 \mathrm{Mcal}$ of $\mathrm{NE}_{\mathrm{L}} / \mathrm{kg}$ of $\mathrm{DM}$, which supplied 10.32 Mcal of $\mathrm{NE}_{\mathrm{L}} / \mathrm{d}$ and is equal to the maintenance energy requirement of a $650-\mathrm{kg}$ mature lactating cow (NRC, 1989). Under practical feeding situations, it is unlikely that diets with energy content similar to this would be fed at the low levels needed for maintenance. However, an energy content of $1.72 \mathrm{Mcal}$ of $\mathrm{NE}_{\mathrm{I}} / \mathrm{kg}$ of $\mathrm{DM}$ also was used when calculating the DMI requirements for 
Table 3. Precision of predictions for flow of nonammonia nonmicrobial N (NANMN) to the small intestine of cattle by various models as measured by the mean square prediction error (MSPE) criterion.

\begin{tabular}{lcccc}
\hline & & \multicolumn{2}{c}{ Percentage of MSPE attributable to } \\
\cline { 3 - 5 } Prediction $^{1}$ & RMSPE $^{2}$ & Mean bias & Slope bias & Dispersion \\
\cline { 3 - 5 } & $(\mathrm{g} / \mathrm{d})$ & & & \\
Tabulated values & 89.34 & 36.87 & 41.70 & 21.43 \\
4\% linear reduction & 70.00 & 5.04 & 62.36 & 32.60 \\
Eq. 1 adjustment & 99.35 & 0.00 & 27.11 & 72.89 \\
Eq. 5 adjustment & 104.63 & 56.69 & 28.14 & 15.18 \\
Eq. 5 evaluation & 82.71 & 47.32 & 28.38 & 24.30 \\
\hline
\end{tabular}

${ }^{1}$ Values correspond to the following: Tabulated values = prediction of NANMN for the data set in Appendix Table 1 using values from Table 1; $4 \%$ linear reduction = prediction of NANMN for the data set in Appendix Table 1 after reducing values in Table 1 by $4 \%$ for each multiple of maintenance energy intake (6 kg DMI) above maintenance; eq. 1 adjustment $=$ prediction of NANMN for the data set in Appendix Table 1 using eq. $1\left\{\right.$ RUP $_{\text {adj } 1}=100-([R D T P \times$ MPIAF $\left.]+N P N)\right\}$; eq. 5 adjustment $=$ prediction of NANMN for the data set in Appendix Table 1 using eq. $5\left[\operatorname{RUP}_{\text {adj } 2}=\frac{100-\text { NPN }}{1+e^{-\left(\frac{\text { DMI }-c}{7.18}\right)}}\right]$; and eq. 5 evaluation $=$ prediction of NANMN

for the data set in Appendix Table 2 using eq. 5.

${ }^{2} \mathrm{RMSPE}=$ Root mean square prediction error

cows producing $>40 \mathrm{~kg}$ of milk/d (NRC, 1989) and was similar to the energy concentration of most of the diets represented in the model development database (Appendix Table 1).

The relationship between observed or residual passage of NANMN to the duodenum and predicted passage of NANMN to the duodenum after increasing RUP values by 4 percentage units for each multiple increase in MEI above maintenance is shown in Figure 2. De-

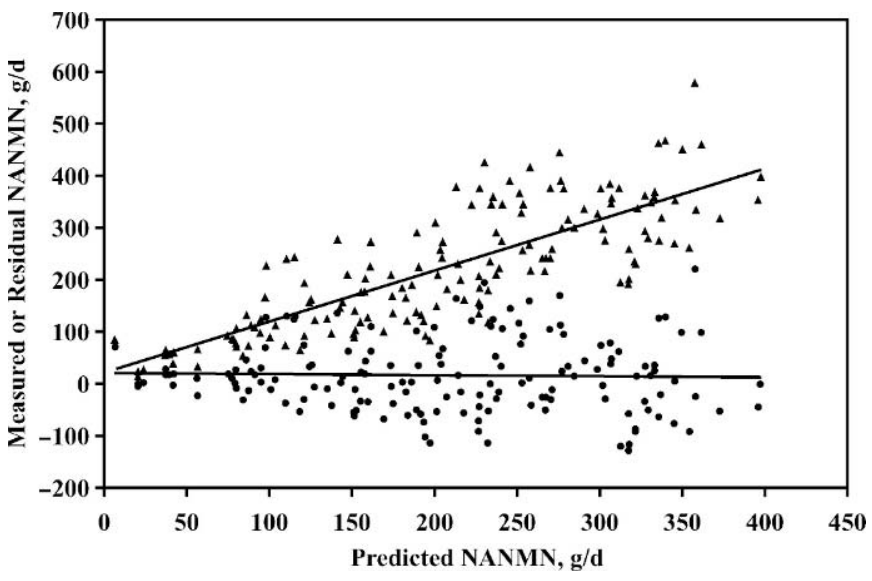

Figure 2. Relationship between measured $(\mathbf{\Delta})$ or residual ( (measured - predicted) passage of nonammonia nonmicrobial $\mathrm{N}$ (NANMN) and predicted NANMN at the duodenum of dairy cows after increasing tabular values for the RUP content of feeds by 4 percentage units per multiple increase in maintenance energy intake to predict the passage of NANMN. Measured NANMN $=0.976 \pm$ $0.056 \times$ predicted NANMN $+20.74 \pm 12.73(P<0.01) ; \mathrm{R}^{2}=0.6567 ;$ root mean square prediction error $=70.00 \mathrm{~g}$ of NANMN/d. Residual NANMN $=-0.025 \pm 0.056 \times$ predicted NANMN $+20.71 \pm 12.73(P>$ $0.6) ; R^{2}=0.0012$. creasing the RUP content of feeds by 4 percentage units per multiple of maintenance energy intake resulted in a RMSPE of $70.00 \mathrm{~g}$ of NANMN/d (Table 3) and a SEY of $57.01 \mathrm{~g}$ of NANMN/d. The decrease in the slope of the regression between predicted and measured passage of NANMN compared with that of Figure 1, along with the decrease in the RMSPE, indicates that increasing the RUP content of feeds by 4 percentage units for each multiple increase in MEI above maintenance improved the accuracy of prediction of passage of NANMN to the duodenum compared with the tabular values. This adjustment removed most of the mean bias, but a significant slope bias remained. Because increasing RUP as a function of MEI improved the accuracy of prediction of NANMN passage to the duodenum, but did not eliminate all bias of prediction, additional adjustment equations were required.

When the ruminal availabilities of $\mathrm{N}$ and energy are not adequately balanced in the rumen, an uncoupling of fermentation may occur (Hespell and Bryant, 1979; Stern and Hoover, 1979). For diets containing 17\% CP, only $2.5 \mathrm{~kg}$ of DM are needed to supply the $\mathrm{CP}$ requirement for maintenance of mature cows. As with the situation for energy, it is unlikely that a small amount of feed would be offered with a high content of CP. However, the level of CP chosen was similar to that of the diets represented in the model development data set (Appendix Table 1). Because a smaller amount of DM can be used to supply the maintenance requirement for protein than the maintenance requirement for energy, the potential must exist for the change in RUP to be different per unit of MEI than per unit of MCPI. Therefore, a 4 percentage unit increase in RUP values for 
each multiple increase in MCPI above maintenance was used to estimate NANMN passage to the duodenum. Changing the adjustment to the equation from an energy basis to a CP basis improved the accuracy of predicting the mean passage of NANMN to the duodenum but had no effect on bias of prediction (data not shown).

To correct the linear bias, an adjustment factor based on MCPI was developed. Iteration was used to determine the optimal unit change per multiple of MCPI and the MCPI that equates to tabulated RUP values. Iterations were evaluated by comparing the resulting variation around the regression of predicted and measured passage of NANMN to the duodenum. Also, NPN content of the diet was not included in measurements of passage of feed CP (NANMN) to the duodenum because it is degraded to $\mathrm{NH}_{3}$ in the rumen. Therefore, an adjustment was made to the equation to correct for NPN content of the feed. The following equation was developed for adjusting the RUP contents of feeds, expressed as a percentage of $\mathrm{CP}$, per multiple of MCPI above maintenance.

$$
\mathrm{RUP}_{\mathrm{adj} 1}=100-([\mathrm{RDTP} \times \mathrm{MPIAF}]+\mathrm{NPN})
$$

where $R U P_{a d j 1}$ is the adjusted percentage of RUP in CP of a feed used to predict passage of $\mathrm{CP}$ to the duodenum, RDTP is the percentage of ruminally degradable true protein in a feed, MPIAF is an adjustment factor for MCPI of cows, and NPN is expressed as a percentage of $\mathrm{CP}$ and is considered to be ruminally degradable. Ruminally degradable true protein was calculated as

$$
\mathrm{RDTP}=100-\mathrm{RUP}_{\mathrm{tab}}-\mathrm{NPN}
$$

where RUP $\mathrm{tab}_{\text {ta }}$ is the percentage of RUP for an individual feed reported in Table 1. The adjustment factor for MCPI was calculated as

$$
\text { MPIAF }=1-\{0.13 \times[(\mathrm{DMI} / 2.5)-9.56]\}
$$

where DMI is the measured or expected DMI for the cows and is expressed in $\mathrm{kg} / \mathrm{d}$, the 2.5 represents the $\mathrm{kg}$ of DM needed to meet the CP requirement for maintenance of a $650-\mathrm{kg}$ mature cow when the diet contains $17 \% \mathrm{CP}$, and the 0.13 and 9.56 are constants determined using an iterative process to adjust the unit change per multiple increase in MCPI to correct the linear bias.

An evaluation of predicted and measured passage of NANMN to the duodenum of dairy cows based on adjustments using eq. 1 previously presented is presented in Figure 3. When applying the adjustment of eq. 1 to individual feeds, both slope and mean bias were lowered (Table 3). Equation 1 has a SEY of $52.01 \mathrm{~g}$

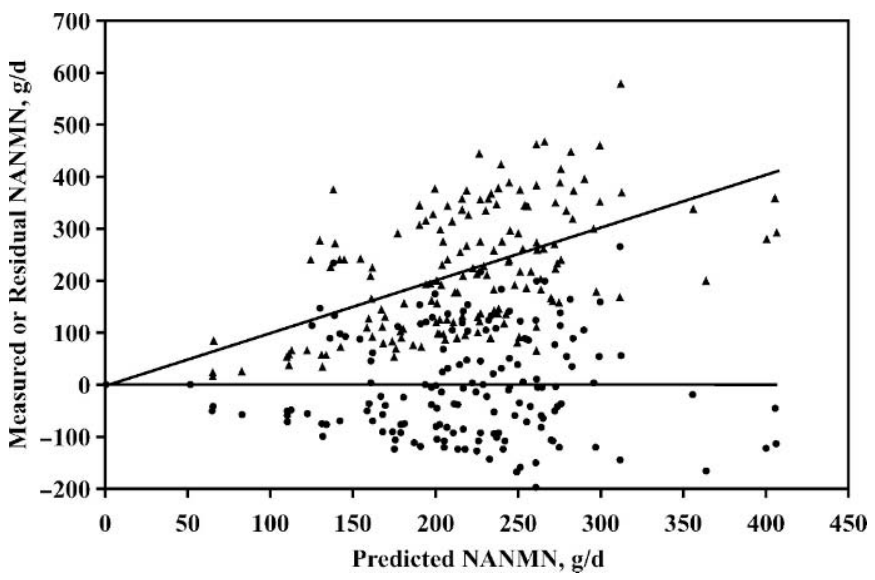

Figure 3. Relationship between measured $(\mathbf{A})$ or residual $(\mathbf{O}$ (measured - predicted) passage of nonammonia nonmicrobial $\mathrm{N}$ (NANMN) and predicted NANMN at the duodenum of dairy cows after increasing tabular values for the RUP content of feeds using a linear function of maintenance protein intake to predict the passage of NANMN. Measured NANMN $=1.00 \pm 0.131 \times$ predicted NANMN $-0.01 \pm 29.88(P<0.01) ; R^{2}=0.2711 ;$ root mean square prediction error $=99.35 \mathrm{~g}$ of NANMN/d. Residual NANMN $=0.00 \pm 0.13 \times$ predicted NANMN $+0.009 \pm 29.88(P>0.9) ; R^{2}=0.0000$.

of NANMN/d and a RMSPE of $99.35 \mathrm{~g}$ of NANMN/d. However, at low DMI, eq. 1 will predict negative RUP values for some feeds, and at high DMI, eq. 1 will predict RUP values for some feeds in excess of $100 \%$ of CP. Also, the multiple coefficient of determination $\left(R^{2}\right)$ between measured values and values predicted using eq. 1 was only 0.27 . This suggests that a linear adjustment based on maintenance protein intake was inadequate for adjusting tabulated RUP values of feeds and that the actual relationship between the RUP content of feeds and feed intake may be nonlinear.

A nonlinear adjustment equation was considered to prevent adjusted RUP values from going outside the biologically possible range of 0 to $100 \%$ of CP. A sigmoidal (logistic) curve was chosen to represent the RUP content of a feed as DMI was increased. At low DMI, fractional passage rate from the rumen is relatively low, and the majority of protein in feed is degraded in the rumen. As DMI increases, fractional passage rate increases so that both the quantity and proportion of feed protein escaping degradation and reaching the duodenum increases. At high DMI, there is only a small increase in the proportion of CP that escapes ruminal degradation, and a plateau is reached in measured RUP values.

The specific form of the sigmoidal curve chosen to describe the change in RUP values was

$$
y=\frac{a}{1+e^{-\left(\frac{\mathrm{DMI}-c}{b}\right)}}
$$


where $y$ is the apparent percentage of RUP in a feed adjusted to a given DMI, $a$ represents the upper asymptote or highest possible RUP value for a feed, DMI is the observed (or expected) DMI in kilograms, $b$ is a constant used to describe the range in DMI over which the majority of change in RUP values occurs, and $c$ is a constant equal to the DMI at the inflection point of the RUP curve (Koops and Grossman, 1991).

Tabular values (Table 1) for the percentage of RUP in feeds were largely determined in vitro or in animals consuming between 1 and $3 \times$ their maintenance energy requirement ( 6 to $18 \mathrm{~kg}$ of DMI). Therefore, a series of $c$ values was generated that resulted in RUP values equal to tabular values. For this process, $a$ was set to $100, b$ to 7 , and DMI to 12 . The upper asymptote of the equation $(a)$ was set to 100 because that would represent complete passage of $\mathrm{CP}$ in a feed, $b$ was set to 7 to represent approximately $4 \times$ the standard deviation for DMI (Koops and Grossman, 1991), and DMI was set to 12 to represent $2 \times$ the maintenance energy requirement of lactating cows. While holding these parameters constant, $c$ was estimated for various values of $y$. This process was then repeated after changing DMI to 15, which represented the DMI needed to supply approximately $2.5 \times$ the maintenance energy requirement for lactating cows. Linear relationships were observed between the values for $c$ and $y$, which had identical slopes but differed in the intercept by the same amount as the change in DMI. Therefore, $c$ was described as a linear function of $\mathrm{RUP}_{\text {tab }}$ with the intercept of this function being an indicator of the inflection point of the RUP adjustment curve.

Iteration was used to determine values for the intercept of the linear relationship between $c$ and $\mathrm{RUP}_{\text {tab}}$, and $b$ in the nonlinear curve that maximized the $\mathrm{R}^{2}$ for the regression of predicted and measured NANMN to the duodenum under the condition that the slope of this regression did not differ from unity, whereas the intercept did not differ from zero. The parameters estimated from the iterations were part of the nonlinear equation. However, the constraints used in generating them were based on the linear regression between measured and predicted data. Because NPN in feeds must be excluded from the predictions for them to be comparable with observed flows of NANMN, the upper asymptote of the nonlinear function $(a)$ was set to 100 minus the NPN for each feed, where NPN was expressed as a percentage of $\mathrm{CP}$. This process resulted in the following equation being accepted for predicting an adjusted RUP as a percentage of the $\mathrm{CP}$ in a feed at a specific DMI:

$$
\mathrm{RUP}_{\mathrm{adj} 2}=\frac{100-\mathrm{NPN}}{1+e^{-\left(\frac{\mathrm{DMI}-c}{7.18}\right)}}
$$

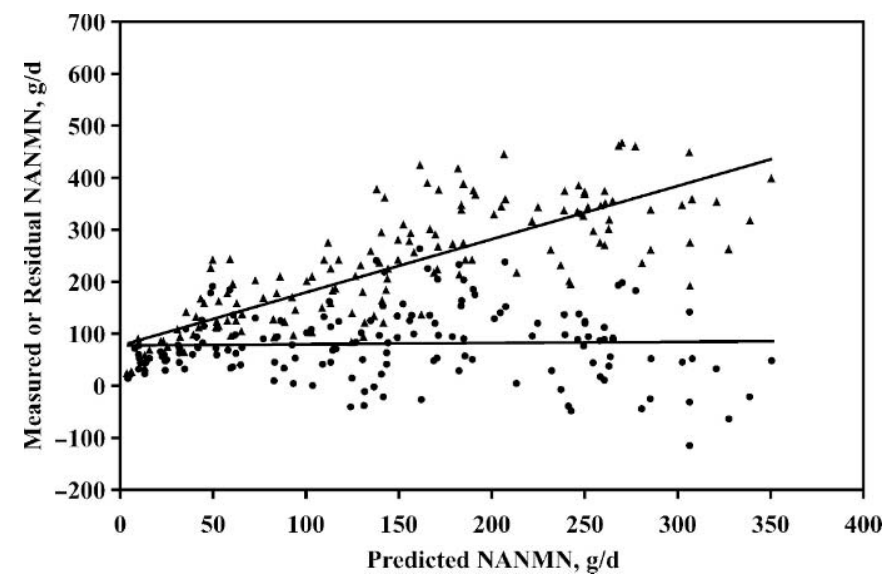

Figure 4. Relationship between measured $(\mathbf{\Delta})$ or residual ( (measured - predicted) passage of nonammonia nonmicrobial $\mathrm{N}$ (NANMN) and predicted NANMN at the duodenum of dairy cows after increasing tabular values for the RUP content of feeds using a nonlinear function of maintenance protein intake to predict the passage of NANMN. Measured NANMN $=1.01 \pm 0.060 \times$ predicted NANMN $+76.91 \pm 10.03(P<0.01) ; R^{2}=0.6496$; root mean square prediction error $=104.63 \mathrm{~g}$ of NANMN/d. Residual NANMN $=0.01$ $\pm 0.060 \times$ predicted NANMN $+76.89 \pm 10.03(P>0.8) ; \mathrm{R}^{2}=0.0003$

where $c=27.36-0.1253 \times \mathrm{RUP}_{\text {tab }}$.

Equation 5 eliminated both linear and mean bias from the prediction of NANMN passage to the duodenum (Figure 4) and maintained the $\mathrm{RUP}_{\mathrm{adj} 2}$ values in the biologically allowable range of 0 to $100 \%$ of the CP. Equation 5 had a SEY of $69.29 \mathrm{~g}$ of NANMN/d and a RMSPE of $104.63 \mathrm{~g}$ of NANMN/d (Table 3). Therefore, adjustments to the RUP content of feeds using eq. 5 were only slightly superior to those using eq. 1 and were slightly inferior to adjusting the RUP content of feeds by 4 percentage units for each multiple increase in maintenance energy intake in their ability to predict flow of NANMN at the small intestine. However, use of eq. 5 was concluded to be most optimal because its predictive ability was similar to the other approaches considered and it maintained predicted RUP values in the biologically valid range of 0 to $100 \%$ of $\mathrm{CP}$.

The relationship between measured and predicted passage of NANMN to the duodenum for the data set used for evaluation of eq. 5 (Appendix Table 2) is presented in Figure 5. Use of eq. 5 to predict passage of NANMN to the duodenum in these experiments did not eliminate the bias of prediction. However, failure of the equation to remove all bias of prediction should not necessarily be considered evidence that the equation is incorrect. The data set used for evaluation purposes was somewhat limited in number and range of the observations (Appendix Table 2). The data set used for evaluation also contained data from steers consuming diets that were somewhat different than those repre- 


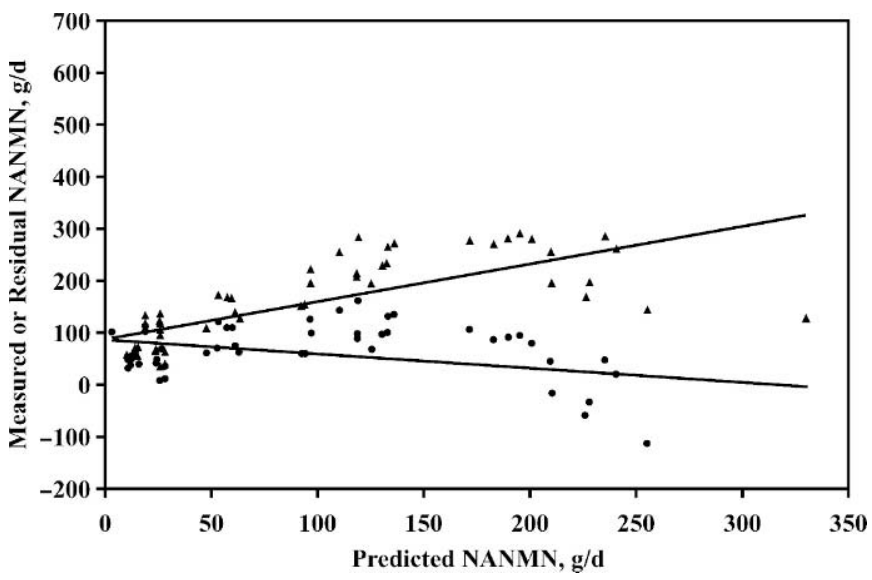

Figure 5. Relationship between measured $(\boldsymbol{\Delta})$ or residual ( (measured - predicted) passage of nonammonia nonmicrobial $\mathrm{N}$ (NANMN) and predicted NANMN at the duodenum of dairy cows using the evaluation data set after increasing tabular values for the RUP content of feeds using eq. 5 to predict the passage of NANMN: $\mathrm{RUP}_{\mathrm{adj} 2}=\frac{100-\mathrm{NPN}}{1+e^{-\left(\frac{\mathrm{DMI}-\mathrm{c}}{7.18}\right)}}$. Measured NANMN $=0.719 \pm 0.091 \times$ pre-

dicted NANMN $+82.89 \pm 11.25(P<0.01) ; \mathrm{R}^{2}=0.5387$; root mean square prediction error $=47.32 \mathrm{~g}$ of NANMN/d. Residual NANMN $=$ $0.28 \pm 0.091 \times$ predicted NANMN $-82.89 \pm 11.25(P<0.01) ; \mathrm{R}^{2}=$ 0.1518 .

sented in the data set used for model development. Additional observations should increase the power associated with the regression while simultaneously decreasing the impact of any one individual observation to skew the regression (Graybill and Iyer, 1994). Also, additional observations from lactating cows should lessen the impact of the steer data. The mean predicted flow of NANMN to the duodenum differed from the mean measured flow $(P<0.01)$, indicating that eq. 5 was not making satisfactory adjustments to tabulated RUP values for the evaluation data set. The evaluation data set produced a SEY of $56.30 \mathrm{~g} / \mathrm{d}$ with a RMSPE of $82.71 \mathrm{~g} / \mathrm{d}$. The MSPE analysis (Theil, 1966) of the residuals from the evaluation of eq. 5 (Table 3 ) indicated that $47.32 \%$ of the error was attributable to inaccurate prediction of the mean passage of NANMN to the duodenum, $28.38 \%$ of the error was correctable through a linear function of the measured and predicted passages of NANMN at the duodenum, and the final $24.30 \%$ of the error was random variation. St Pierre (2003) suggested that any perceived bias should be evaluated in relation to reported measurement errors to determine its potential impact on the predictive ability of the model. It is likely that differences in the type of diets represented in the model evaluation and model development data sets were negatively impacting the apparent predictive ability of the model. As more data become available, it will be possible to determine whether there

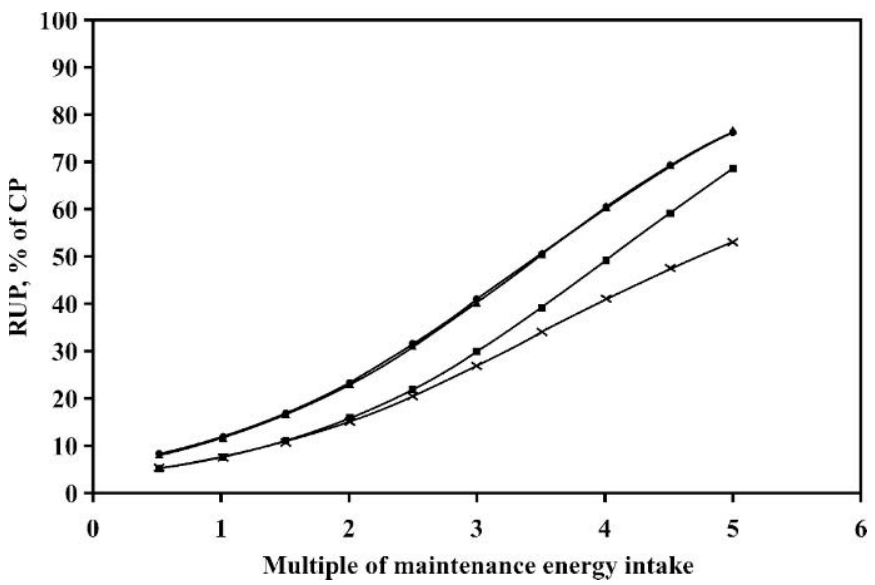

Figure 6. Apparent RUP content of barley grain ( $\mathbf{\square})$, corn grain $(\mathbf{\Delta})$, high moisture corn grain $(\times)$, and sorghum grain $(\bullet)$ at differing multiples of maintenance energy intake as determined using eq. 5: $\mathrm{RUP}_{\mathrm{adj} 2}=\frac{100-\mathrm{NPN}}{1+e^{-\left(\frac{\mathrm{DMI}-c}{7.18}\right)}}$.

are true errors or if the problems uncovered in this exercise are an artifact of the analysis related to abnormalities in the evaluation data set (Mayer and Butler, 1993; Carroll and Galindo, 1998; Oreskes, 1998; Carroll et al., 1999).

Figures $6,7,8,9,10$, and 11 present apparent predicted RUP content of selected feeds at different levels of DMI. Apparent predicted RUP contents of cereal grains as intake increases from 0.5 to $5 \times$ maintenance energy intake ( 3 to $30 \mathrm{~kg}$ DMI) are presented in Figure 6. Similar information for oil seed meals is presented in Figure 7. Apparent predicted RUP contents of oil

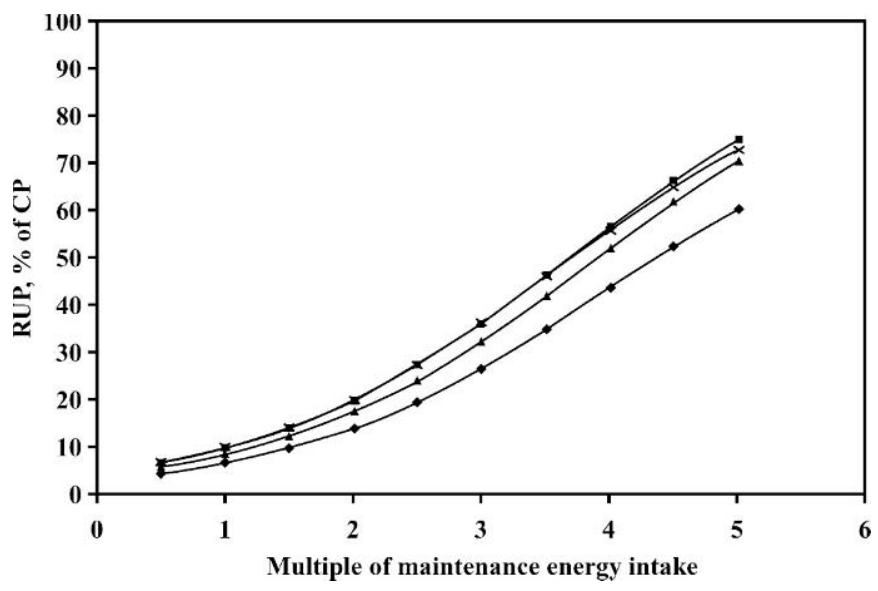

Figure 7. Apparent RUP content of canola seed meal ( $\bullet$ ), solventextracted soybean meal $(\boldsymbol{\Lambda})$, expeller-extracted soybean meal $(\times)$, and cottonseed meal ( $)$ at differing multiples of maintenance energy intake as determined using eq. 5: $\operatorname{RUP}_{\mathrm{adj} 2}=\frac{100-\mathrm{NPN}}{1+e^{-\left(\frac{\mathrm{DMI}-c}{7.18}\right)} \text {. }}$ 


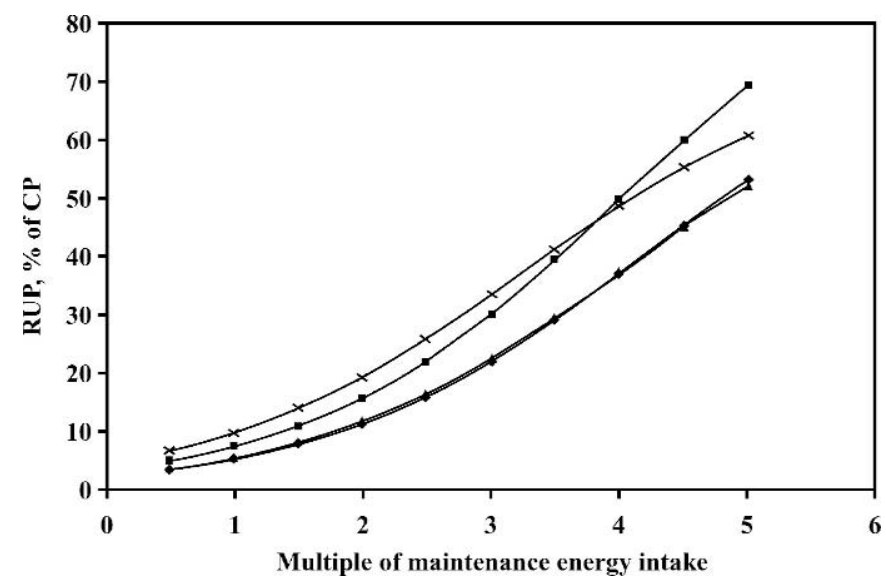

Figure 8. Apparent RUP content of canola seed $(\bullet)$, raw soybeans $(\mathbf{\Lambda})$, roasted soybeans $(\times)$, and whole cottonseed (⿴) at differing multiples of maintenance energy intake as determined using eq. 5: $\mathrm{RUP}_{\mathrm{adj} 2}=\frac{100-\mathrm{NPN}}{1+e^{-\left(\frac{\mathrm{DMI}-c}{7.18}\right)}}$.

seeds at differing multiples of maintenance energy intake are presented in Figure 8, and similar data for forages are presented in Figure 9. Figure 10 presents the apparent predicted RUP content as estimated by eq. 5 for byproduct feeds, and Figure 11 is a similar representation for animal protein meals. All of the example feeds exhibited the expected sigmoidal shape to their apparent predicted RUP content curve. At low DMI, the majority of the CP in most feed is degraded, resulting in a low apparent RUP content of that feed. However, at high DMI, the majority of the $\mathrm{CP}$ in most

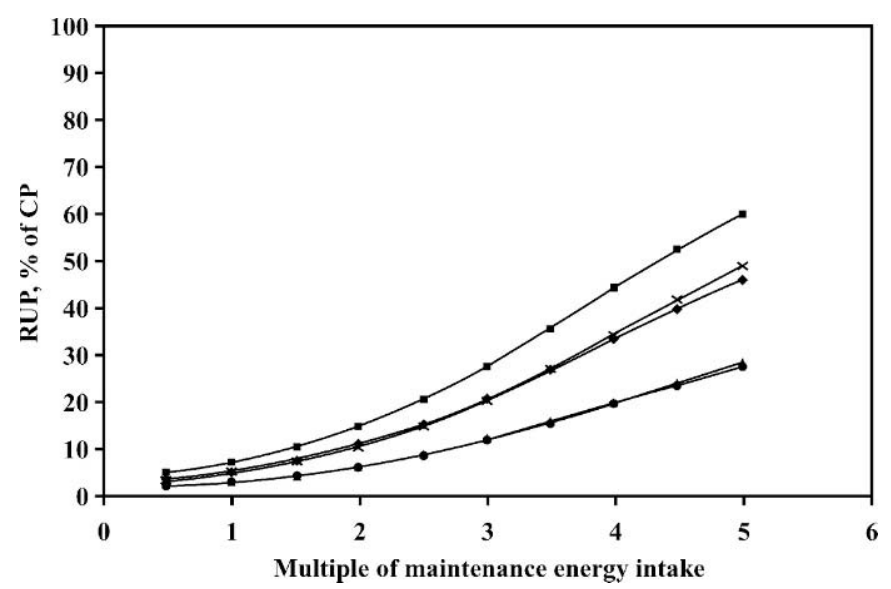

Figure 9. Apparent RUP content of corn silage ( $\bullet$ ), grass silage $(\boldsymbol{\Lambda})$, legume hay $(\times)$, grass hay $(\square)$, and legume silage $(\bullet)$ at differing multiples of maintenance energy intake as determined using eq. 5: $\operatorname{RUP}_{\mathrm{adj} 2}=\frac{100-\mathrm{NPN}}{1+e^{-\left(\frac{\mathrm{DMI}-c}{7.18}\right)}}$.

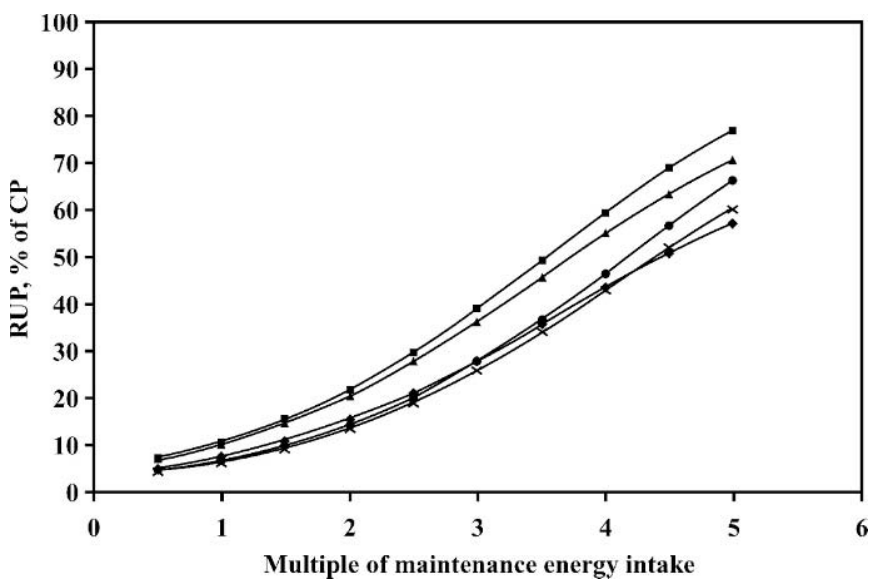

Figure 10. Apparent RUP content of beet pulp ( $\bullet)$, corn distillers grains with solubles $(\boldsymbol{\Delta})$, soybean hulls $(\times)$, dried brewers grains $(\boldsymbol{\square})$, and wheat middlings $(\bullet)$ at differing multiples of maintenance energy intake as determined using eq. 5: $\operatorname{RUP}_{\mathrm{adj} 2}=\frac{100-\mathrm{NPN}}{1+e^{-\left(\frac{\mathrm{DMI}-c}{7.18}\right)}}$.

feed is not degraded in the rumen but passes to the small intestine, resulting in a high apparent RUP content of that feed. At high DMI, a large amount of degradable CP is supplied from feeds that have large quantities of NPN, such as corn silage or legume forages, and smaller amounts of degradable CP are supplied from other feeds. The amount of RDP and RUP that is supplied from these feeds when diets with a typical forage content are fed to lactating dairy cows at high DMI appears adequate to support microbial protein synthesis and the predicted passage of RUP to the small intestine.

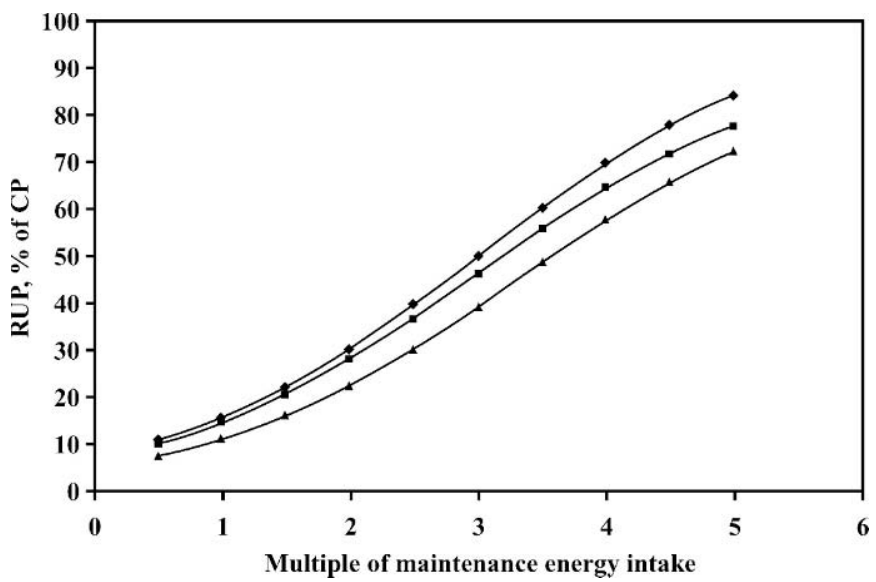

Figure 11. Apparent RUP content of blood meal $(\diamond)$, fish meal $(\boldsymbol{\Lambda})$, and feather meal (ם) at differing multiples of maintenance energy intake as determined using eq. 5: $\mathrm{RUP}_{\mathrm{adj} 2}=\frac{100-\mathrm{NPN}}{1+e^{-\left(\frac{\mathrm{DMI}-c}{7.18}\right)} \text {. }}$ 


\section{CONCLUSIONS}

Current tabular values for the RUP content of feeds do not allow accurate prediction of NANMN passage to the duodenum of lactating dairy cows. Tabular values for RUP can be adjusted using either a linear or nonlinear function of DMI to better predict passage of NANMN. A nonlinear function relating RUP to DMI agreed better with the underlying biology of lactating dairy cows than did a linear function because estimated RUP values for individual feeds remained within the biologically possible range of 0 to $100 \%$ of CP. Both of the equations developed for adjusting tabular RUP values of feeds better predicted the passage of NANMN to the small intestine than did tabular values. The nonlinear equation was able to eliminate the bias in predicting flow of NANMN to the small intestine, but it was not able to completely remove the variation around the line of prediction. This is an indication that, although the concept of adjusting tabulated RUP values based on DMI is correct, other factors are also influencing the apparent RUP content of feeds. When more data for cows consuming larger amounts of DM become available, this equation should be reevaluated for its ability to properly adjust RUP values of feeds reported by NRC. Furthermore, as other data become available that quantify the effects of factors other than DMI on the apparent RUP values of feeds, they should also be incorporated into an adjustment equation to better predict passage of NANMN to the duodenum.

\section{REFERENCES}

Ahvenjarvi, S., A. Vanhatalo, and P. Huhtanen. 2002. Supplementing barley or rapeseed meal to dairy cows fed grass-red clover silage: I. Rumen degradability and microbial flow. J. Anim. Sci. 80:2176-2187.

Aldrich, J. M., L. D. Muller, G. A. Varga, and L. C. Griel. 1993. Nonstructural carbohydrate and protein effects on rumen fermentation, nutrient flow, and performance of dairy cows. J. Dairy Sci. 76:1091-1105.

Bateman, H. G., J. H. Clark, R. A. Patton, C. J. Peel, and C. G. Schwab. 2001a. Accuracy and precision of computer models to predict passage of crude protein and amino acids to the duodenum of lactating cows. J. Dairy Sci. 84:649-664.

Bateman, H. G., J. H. Clark, R. A. Patton, C. J. Peel, and C. G. Schwab. 2001b. Prediction of crude protein and amino acid passage to the duodenum of lactating cows by models compared with in vivo data. J. Dairy Sci. 84:665-679.

Callison, S. L., J. L. Firkins, M. L. Eastridge, and B. L. Hull. 2001. Site of nutrient digestion by dairy cows fed corn of different particle sizes or steam-rolled. J. Dairy Sci. 84:1458-1467.

Cameron, M. R., T. H. Klusmeyer, G. L. Lynch, J. H. Clark, and D. R. Nelson. 1991. Effects of urea and starch on rumen fermentation, nutrient passage to the duodenum, and performance of cows. J. Dairy Sci. 74:1321-1336.

Carroll, R. J., and C. D. Galindo. 1998. Measurement error, biases, and the validation of complex models for blood lead levels in children. Environ. Health Perspect. 106:1535-1539.

Carroll, R. J., J. D. Maca, and D. Ruppert. 1999. Nonparametric regression in the presence of measurement error. Biometrika $86: 541-554$
Choi, C. W., S. Ahvenjarvi, A. Vanhatalo, V. Toivonen, and P. Huhtanen. 2002. Quantitation of the flow of soluble non-ammonia nitrogen entering the omasal canal of dairy cows fed grass silage based diets. Anim. Feed Sci. Technol. 96:203-220.

Christensen, R. A., M. R. Cameron, T. H. Klusmeyer, J. P. Elliott, J. H. Clark, D. R. Nelson, and Y. Yu. 1993. Influence of amount and degradability of dietary protein on nitrogen utilization by dairy cows. J. Dairy Sci. 76:3497-3513.

Christensen, R. A., T. R. Overton, J. H. Clark, J. K. Drackley, D. R. Nelson, and S. A. Blum. 1996. Effects of dietary fat with or without nicotinic acid on nutrient flow to the duodenum of dairy cows. J. Dairy Sci. 79:1410-1424.

Clark, J. H., and C. L. Davis. 1983. Future improvement of milk production; potential for nutritional improvement. J. Anim. Sci. 57:750-764.

Clark, J. H., T. H. Klusmeyer, and M. R. Cameron. 1992. Microbial protein synthesis and flows of nitrogen fractions to the duodenum of dairy cows. J. Dairy Sci. 75:2304-2323.

Crocker, L. M., E. J. DePeters, J. G. Fadel, H. Perez-Monti, S. J. Taylor, J. A. Wyckoff, and R. A. Zinn. 1998. Influence of processed corn grain in diets of dairy cows on digestion of nutrients and milk composition. J. Dairy Sci. 81:2394-2407.

Cunningham, K. D., M. J. Cecava, and T. R. Johnson. 1993. Nutrient digestion, nitrogen, and amino acid flows in lactating cows fed soybean hulls in place of forage or concentrate. J. Dairy Sci. 76:3523-3535.

Cunningham, K. D., M. J. Cecava, and T. R. Johnson. 1994. Flows of nitrogen and amino acids in dairy cows fed diets containing supplemental feather meal and blood meal. J. Dairy Sci. 77:3666-3675.

Elizalde, J. C., N. R. Merchen, and D. B. Faulkner. 1999. Supplemental cracked corn for steers fed fresh alfalfa: II. Protein and amino acid digestion. J. Anim. Sci. 77:467-475.

Graybill, F. A., and H. K. Iyer. 1994. Regression Analysis: Concepts and Applications. Wadsworth, Inc., Belmont, CA.

Hamali, A. Y., A. La Manna, and F. N. Owens. 2001a. Effect of energy and nitrogen sources on efficiency of microbial protein synthesis in the rumen of steers fed concentrate or roughage diets. J. Trop. Agric. Food Sci. 29:223-237.

Hamali, A. Y., R. Puccala, and F. N. Owens. 2001b. Effects of level and physical form of cottonseed hulls on microbial protein synthesis in the rumen of steers fed high concentrate diets. J. Trop. Agric. Food Sci. 29:103-111.

Hespell, R. B., and M. P. Bryant. 1979. Efficiency of rumen microbial growth: Influence of some theoretical and experimental factors on YATP. J. Anim. Sci. 49:1640-1659.

Holden, L. A. 1994. Effects of alfalfa and orchard grass on digestion by dairy cows. J. Dairy Sci. 77:2580-2594.

Horner, J. L., C. E. Coppock, J. R. Moya, J. M. Labore, and J. K. Lanham. 1988. Effects of niacin and whole cottonseed on ruminal fermentation, protein degradability, and nutrient digestibility. J. Dairy Sci. 71:1239-1247.

Hvelplund, T., and J. Madsen. 1985. Amino acid passage to the small intestine in dairy cows compared with estimates of microbial protein and undegraded dietary protein from analysis on the feed. Acta Agric. Scand. 25(Suppl.):21-36.

Ipharraguerre, I. R., Z. Shabi, J. H. Clark, and D. E. Freeman. 2002. Ruminal fermentation and nutrient digestion by dairy cows fed varying amounts of soyhulls as a replacement for corn grain. J. Dairy Sci. 85:2890-2904.

Khorasani, G. R., E. K. Okine, and J. J. Kennelly. 1996. Forage source alters nutrient supply to the intestine without influencing milk yield. J. Dairy Sci. 79:862-872.

Klusmeyer, T. H., G. L. Lynch, J. H. Clark, and D. R. Nelson. 1991a. Effects of calcium salts of fatty acids and proportion of forage in diet on ruminal fermentation and nutrient flow to duodenum of cows. J. Dairy Sci. 74:2220-2232.

Klusmeyer, T. H., G. L. Lynch, J. H. Clark, and D. R. Nelson. 1991b. Effects of calcium salts of fatty acids and protein source on ruminal fermentation and nutrient flow to duodenum of cows. J. Dairy Sci. 74:2206-2219. 
Knowlton, K. F., B. P. Glenn, and R. A. Erdman. 1998. Performance, ruminal fermentation, and site of starch digestion in early lactation cows fed corn grain harvested and processed differently. J. Dairy Sci. 81:1972-1984.

Koops, W. J., and M. Grossman. 1991. Applications of a multiphasic growth function to body composition in pigs. J. Anim. Sci. 69:3265-3273

Kung, L., and J. T. Huber. 1983. Performance of high producing cows in early lactation fed protein of varying amounts, sources, and degradability. J. Dairy Sci. 66:227-234.

Lu, C. D., N. A. Jorgensen, and L. D. Satter. 1988. Site and extent of nutrient digestion in lactating dairy cows fed alfalfa protein concentrate or soybean meal. J. Dairy Sci. 71:697-704.

Lykos, T., G. A. Varga, and D. Casper. 1997. Varying degradation rates of total nonstructural carbohydrates: Effects on ruminal fermentation, blood metabolites, and milk production and composition in high producing Holstein cows. J. Dairy Sci. 80:33413355.

Mabjeesh, S. J., A. Arieli, I. Bruckental, S. Zamwell, and H. Tagari. 1996. Effect of type of protein supplementation on duodenal amino acid flow and absorption in lactating dairy cows. J. Dairy Sci. 79:1792-1801.

Mansfield, H. R., and M. D. Stern. 1994. Effects of soybean hulls and lignosulfonate-treated soybean meal on ruminal fermentation in lactating dairy cows. J. Dairy Sci. 77:1070-1083.

Mayer, D. G., and D. G. Butler. 1993. Statistical validation. Ecol. Modell. 68:21-32.

McCarthy, R. D., Jr., T. H. Klusmeyer, J. L. Vicini, J. H. Clark, and D. R. Nelson. 1989. Effects of source of protein and carbohydrate on ruminal fermentation and passage of nutrients to the small intestine of lactating cows. J. Dairy Sci. 72:2002-2016.

McNiven, M. A., M. R. Weisbjerg, and T. Hvelplund. 1995. Influence of roasting on sodium hydroxide treatment of barley on digestion in lactating cows. J. Dairy Sci. 78:1106-1115.

Moe, P. W., and H. F. Tyrrell. 1976. Pages 232-236 in Estimating Metabolizable and Net Energy of Feeds, P. V. Fonnesbeck, L. E. Harris, and L. C. Kearl, ed. 1st Int. Symp. on Feed Composition, Animal Nutrient Requirements, and Computerization of Diets. Utah State University, Logan.

Møller, P. D. 1985. Results of grass silage based rations on the nitrogen absorption in the gastro-intestinal tract of dairy cows applied in the Nordic protein evaluation system. Acta Agric. Scand. 25(Suppl.):49-63.

Narasimhalu, P., E. Teller, M. Vanbelle, M. Foulon, and F. Dasnoy. 1989. Apparent digestibility of nitrogen in rumen and whole tract of Friesian cattle fed direct-cut and wilted grass silages. J. Dairy Sci. 72:2055-2061.

NRC. 1985. Ruminant Nitrogen Usage. National Academy Press, Washington, DC.

NRC. 1989. Nutrient Requirements of Dairy Cattle, 6th rev. ed. National Academy Press, Washington, DC.

NRC. 1996. Nutrient Requirements of Beef Cattle, 7th rev. ed. National Academy Press, Washington, DC.

NRC. 2001. Nutrient Requirements of Dairy Cattle, 7th rev. ed. National Academy Press, Washington, DC.

Oba, M., and M. S. Allen. 2003. Effects of diet fermentability on efficiency of microbial nitrogen production in lactating dairy cows. J. Dairy Sci. 86:195-207.

Oldick, B. S., and J. L. Firkins. 2000. Effects of degree of fat saturation on fiber digestion and microbial protein synthesis when diets are fed twelve times daily. J. Anim. Sci. 78:2412-2420.

O’Mara, F. P., J. J. Murphy, and M. Rath. 1998. Effect of amount of dietary supplement and source of protein on milk production, ruminal fermentation, and nutrient flows in dairy cows. J. Dairy Sci. 81:2430-2439

Oreskes, N. 1998. Evaluation (not validation) of quantitative models. Environ. Health Perspect. 106:1453-1460.

Overton, T. R., M. R. Cameron, J. P. Elliott, J. H. Clark, and D. R. Nelson. 1995. Ruminal fermentation and passage of nutrients to the duodenum of lactating cows fed mixtures of corn and barley. J. Dairy Sci. 78:1981-1998.

Poore, M. H., J. A. Moore, T. P. Eck, R. S. Swingle, and C. B. Theurer. 1993. Effects of fiber source and ruminal starch degradability on site and extent of digestion in dairy cows. J. Dairy Sci. 76:2244-2253

Prange, R. W., M. D. Stern, N. A. Jorgensen, and L. D. Satter. 1984 Site and extent of protein digestion in lactating cows fed alfalfa silage or baled alfalfa hay. J. Dairy Sci. 67:2308-2314.

Putnam, D. E., C. G. Schwab, M. T. Socha, N. L. Whitehouse, N. A. Kierstead, and B. D. Garthwaite. 1997. Effect of yeast culture in the diets of early lactation dairy cows on ruminal fermentation and passage of nitrogen fractions and amino acids to the small intestine. J. Dairy Sci. 80:374-384.

Robinson, P. H., and C. J. Sniffen. 1985. Forestomach and whole tract digestibility for lactating dairy cows as influenced by feeding frequency. J. Dairy Sci. 68:857-867.

Robinson, P. H., C. J. Sniffen, and P. J. Van Soest. 1985. Influence of level of feed intake on digestion and bacterial yield in the forestomachs of dairy cattle. Can. J. Anim. Sci. 65:437-444.

Rode, L. M., D. C. Weakley, and L. D. Satter. 1985. Effect of forage amount and particle size in diets of lactating dairy cows on site of digestion and microbial protein synthesis. Can. J. Anim. Sci. 65:101-111.

Rooke, J. A., H. A. Greife, and D. G. Armstrong. 1985. The digestion by cattle of silage-containing diets fed at two dry matter intakes. 1 . Digestion of organic matter and nitrogen. Br. J. Nutr. 53:691-708.

Santos, F. A. P., J. E. P. Santos, C. B. Theurer, and J. T. Huber. 1998. Effects of rumen undegradable protein on dairy cow performance: A 12 year literature review. J. Dairy Sci. 81:3182-3213.

Shabi, Z., A. Arieli, I. Bruckental, Y. Aharoni, S. Zamwel, A. Bor, and H. Tagari. 1998. Effect of the synchronization of the degradation of dietary crude protein and organic matter and feeding frequency on ruminal fermentation and flow of digesta in the abomasum of dairy cows. J. Dairy Sci. 81:1991-2000.

Snedecor, G. W., and W. G. Cochran. 1989. Statistical Methods, 8th ed. Iowa State University Press, Ames, IA.

Sniffen, C. J., and P. H. Robinson. 1987. Microbial growth and flow as influenced by dietary manipulations. J. Dairy Sci. 70:425-441.

Song, M. K., and J. J. Kennelly. 1989. Effect of ammoniated barley silage on ruminal fermentation, nitrogen supply to the small intestine, ruminal and whole tract digestion, and milk production of Holstein cows. J. Dairy Sci. 72:2981-2990.

Stern, M. D., and W. H. Hoover. 1979. Methods for determining and factors affecting rumen microbial protein synthesis: A review. J. Anim. Sci. 49:1590-1603.

Stern, M. D., L. M. Rode, R. W. Prange, R. H. Stauffacher, and L. D. Satter. 1983. Ruminal protein degradation of corn gluten meal in lactating dairy cattle fitted with duodenal T-type cannulae. J. Anim. Sci. 56:194-205.

St Pierre, N. R. 2003. Reassessment of biases in predicted nitrogen flows to the duodenum by NRC 2001. J. Dairy Sci. 86:344-350.

Tamminga, S., C. J. Van Der Koelen, and A. M. Van Vuuren. 1979. Effect of the level of feed intake on nitrogen entering the small intestine of dairy cows. Livest. Prod. Sci. 6:255-262.

Tesfa, A. T. 1993. Effects of rape-seed oil supplementation on digestion, microbial protein synthesis and duodenal microbial amino acid composition in ruminants. Anim. Feed Sci. Technol. 41:313-328.

Theil, H. 1966. Measuring the accuracy of point predictions. Pages 15-37 in Applied Economic Forecasting. Rand McNally Corp., Chicago, IL.

Tyrrell, H. F., and P. W. Moe. 1975. Effect of intake on digestive efficiency. J. Dairy Sci. 58:1151-1161.

Volden, H. 1999. Effects of level of feeding and ruminally undegraded protein on ruminal bacterial protein synthesis, escape of dietary protein, intestinal amino acid profile, and performance of dairy cows. J. Anim. Sci. 77:1905-1918. 


\section{APPENDIX}

Table A1. Data set used to derive constants for prediction equations.

\begin{tabular}{|c|c|c|c|}
\hline Reference & $\begin{array}{l}\text { Measured } \\
\text { NANMN }^{1}\end{array}$ & $\begin{array}{l}\text { Predicted } \\
\text { NANMN }^{2}\end{array}$ & DMI \\
\hline & \multicolumn{2}{|c|}{$\longrightarrow(\mathrm{g} / \mathrm{d})$} & $(\mathrm{kg} / \mathrm{d})$ \\
\hline Aldrich et al. (1993) & $\begin{array}{l}274 \\
351 \\
315 \\
396\end{array}$ & $\begin{array}{l}258 \\
321 \\
339 \\
351\end{array}$ & $\begin{array}{l}25 \\
24.9 \\
26.7 \\
25.3\end{array}$ \\
\hline Cameron et al. (1991) & $\begin{array}{l}239 \\
239 \\
266 \\
254\end{array}$ & $\begin{array}{l}190 \\
186 \\
171 \\
158\end{array}$ & $\begin{array}{l}23.1 \\
23 \\
21.6 \\
21\end{array}$ \\
\hline Christensen et al. (1993) & $\begin{array}{l}374 \\
387 \\
365 \\
576\end{array}$ & $\begin{array}{l}303 \\
255 \\
265 \\
239\end{array}$ & $\begin{array}{l}21.3 \\
21 \\
20.7 \\
21.5\end{array}$ \\
\hline Christensen et al. (1996) & $\begin{array}{l}345 \\
296 \\
354 \\
334\end{array}$ & $\begin{array}{l}171 \\
185 \\
191 \\
247\end{array}$ & $\begin{array}{l}24.2 \\
22.6 \\
23.6 \\
22.7\end{array}$ \\
\hline Cunningham et al. (1993) & $\begin{array}{l}261 \\
272 \\
233 \\
258 \\
189\end{array}$ & $\begin{array}{l}328 \\
307 \\
281 \\
286 \\
307\end{array}$ & $\begin{array}{l}24.1 \\
23.5 \\
22.3 \\
22.7 \\
23.2\end{array}$ \\
\hline Cunningham et al. (1994) & $\begin{array}{l}144 \\
190 \\
234 \\
240\end{array}$ & $\begin{array}{r}94 \\
115 \\
139 \\
149\end{array}$ & $\begin{array}{l}17.8 \\
17.9 \\
18 \\
17.5\end{array}$ \\
\hline Holden (1994) & $\begin{array}{l}134 \\
184\end{array}$ & $\begin{array}{l}162 \\
116\end{array}$ & $\begin{array}{l}19.2 \\
16.3\end{array}$ \\
\hline Horner et al. (1988) & $\begin{array}{l}78 \\
83 \\
52 \\
70\end{array}$ & $\begin{array}{l}21 \\
23 \\
24 \\
23\end{array}$ & $\begin{array}{l}8.1 \\
8.4 \\
8.5 \\
8.5\end{array}$ \\
\hline Hvelplund and Madsen (1985) & $\begin{array}{r}168 \\
108 \\
86 \\
54 \\
131 \\
111 \\
65 \\
58 \\
140 \\
279 \\
359 \\
292 \\
97 \\
156 \\
92 \\
106 \\
26\end{array}$ & $\begin{array}{r}92 \\
51 \\
22 \\
11 \\
41 \\
41 \\
9 \\
10 \\
35 \\
149 \\
142 \\
141 \\
39 \\
44 \\
32 \\
30 \\
5\end{array}$ & $\begin{array}{r}13.5 \\
14.2 \\
7.1 \\
7.3 \\
12.7 \\
12.9 \\
6.4 \\
7.1 \\
14.1 \\
13.6 \\
13.5 \\
11 \\
13 \\
11.1 \\
10.6 \\
5.5 \\
14.2\end{array}$ \\
\hline Khorasani et al. (1996) & $\begin{array}{l}216 \\
118 \\
147 \\
181\end{array}$ & $\begin{array}{l}169 \\
141 \\
108 \\
114\end{array}$ & $\begin{array}{l}19.6 \\
18.6 \\
16.7 \\
17.2\end{array}$ \\
\hline $\begin{array}{l}\text { Klusmeyer et al. (personal } \\
\text { communication, 1998) }\end{array}$ & $\begin{array}{l}298 \\
446 \\
383 \\
460\end{array}$ & $\begin{array}{l}308 \\
261 \\
259 \\
222\end{array}$ & $\begin{array}{l}24.2 \\
24.1 \\
22.5 \\
23.8\end{array}$ \\
\hline
\end{tabular}

Continued
Table A1 (Continued). Data set used to derive constants for prediction equations.

\begin{tabular}{|c|c|c|c|}
\hline Reference & $\begin{array}{l}\text { Measured } \\
\text { NANMN }^{1}\end{array}$ & $\begin{array}{l}\text { Predicted } \\
\text { NANMN }^{2}\end{array}$ & DMI \\
\hline & \multicolumn{2}{|c|}{$\longrightarrow(\mathrm{g} / \mathrm{d})$} & $(\mathrm{kg} / \mathrm{d})$ \\
\hline $\begin{array}{l}\text { Klusmeyer et al. (personal } \\
\text { communication, 1998) }\end{array}$ & $\begin{array}{l}458 \\
465 \\
443 \\
344\end{array}$ & $\begin{array}{l}277 \\
270 \\
207 \\
183\end{array}$ & $\begin{array}{l}23 \\
23.7 \\
22.3 \\
22.4\end{array}$ \\
\hline Klusmeyer et al. (1991b) & $\begin{array}{l}335 \\
324 \\
343 \\
342\end{array}$ & $\begin{array}{l}263 \\
307 \\
247 \\
269\end{array}$ & $\begin{array}{l}25.1 \\
23.8 \\
23.4 \\
22.3\end{array}$ \\
\hline Klusmeyer et al. (1991a) & $\begin{array}{l}357 \\
372 \\
344 \\
314\end{array}$ & $\begin{array}{l}286 \\
250 \\
252 \\
225\end{array}$ & $\begin{array}{l}25.5 \\
24 \\
24.7 \\
23.3\end{array}$ \\
\hline Knowlton et al. (1998) & $\begin{array}{l}269 \\
349 \\
318 \\
333\end{array}$ & $\begin{array}{l}261 \\
261 \\
264 \\
246\end{array}$ & $\begin{array}{l}23.4 \\
23.4 \\
24.4 \\
23.7\end{array}$ \\
\hline Kung and Huber (1983) & $\begin{array}{l}204 \\
183 \\
222 \\
161\end{array}$ & $\begin{array}{l}143 \\
143 \\
170 \\
141\end{array}$ & $\begin{array}{l}17.7 \\
17.7 \\
18.5 \\
17.2\end{array}$ \\
\hline Lu et al. (1988) & $\begin{array}{l}160 \\
176\end{array}$ & $\begin{array}{l}53 \\
57\end{array}$ & $\begin{array}{l}13 \\
12.1\end{array}$ \\
\hline Lykos et al. (1997) & $\begin{array}{l}193 \\
199 \\
228\end{array}$ & $\begin{array}{l}243 \\
242 \\
237\end{array}$ & $\begin{array}{l}25.8 \\
25.9 \\
25.9\end{array}$ \\
\hline Mabjeesh et al. (1996) & $\begin{array}{l}208 \\
256 \\
224 \\
288\end{array}$ & $\begin{array}{l}126 \\
135 \\
144 \\
169\end{array}$ & $\begin{array}{l}17.6 \\
17.8 \\
18.6 \\
19.1\end{array}$ \\
\hline Mansfield and Stern (1994) & $\begin{array}{l}344 \\
368 \\
357 \\
373\end{array}$ & $\begin{array}{l}205 \\
250 \\
207 \\
190\end{array}$ & $\begin{array}{l}20.2 \\
20.8 \\
20.7 \\
19.1\end{array}$ \\
\hline McCarthy, Jr. et al. (1989) & $\begin{array}{l}373 \\
372 \\
307 \\
289\end{array}$ & $\begin{array}{l}239 \\
250 \\
152 \\
156\end{array}$ & $\begin{array}{l}23.3 \\
24.2 \\
20.5 \\
20.9\end{array}$ \\
\hline McNiven et al. (1995) & $\begin{array}{r}95 \\
124 \\
121\end{array}$ & $\begin{array}{l}60 \\
57 \\
51\end{array}$ & $\begin{array}{l}14 \\
13.6 \\
13.1\end{array}$ \\
\hline Møller (1985) & $\begin{array}{r}125 \\
178 \\
102 \\
156 \\
111 \\
165 \\
73 \\
136\end{array}$ & $\begin{array}{r}83 \\
130 \\
64 \\
113 \\
51 \\
77 \\
32 \\
65\end{array}$ & $\begin{array}{l}16 \\
16.3 \\
15.7 \\
16.2 \\
13.5 \\
13.4 \\
12.5 \\
13.5\end{array}$ \\
\hline Narasimhalu et al. (1989) & $\begin{array}{l}76 \\
85\end{array}$ & $\begin{array}{r}7 \\
10\end{array}$ & $\begin{array}{r}9.7 \\
11.2\end{array}$ \\
\hline Overton et al. (1995) & $\begin{array}{l}327 \\
271 \\
276 \\
239 \\
224\end{array}$ & $\begin{array}{l}201 \\
179 \\
156 \\
117 \\
113\end{array}$ & $\begin{array}{l}22.8 \\
22.1 \\
21.3 \\
19.5 \\
19.6\end{array}$ \\
\hline
\end{tabular}


Table A1 (Continued). Data set used to derive constants for prediction equations.

\begin{tabular}{|c|c|c|c|}
\hline Reference & $\begin{array}{l}\text { Measured } \\
\text { NANMN }^{1}\end{array}$ & $\begin{array}{l}\text { Predicted } \\
\text { NANMN }^{2}\end{array}$ & DMI \\
\hline & \multicolumn{2}{|c|}{$\longrightarrow(\mathrm{g} / \mathrm{d})$} & $(\mathrm{kg} / \mathrm{d})$ \\
\hline Poore et al. (1993) & $\begin{array}{l}272 \\
210 \\
259 \\
216\end{array}$ & $\begin{array}{l}185 \\
183 \\
232 \\
213\end{array}$ & $\begin{array}{l}20.7 \\
20.7 \\
21.3 \\
20.7\end{array}$ \\
\hline Prange et al. (1984) & $\begin{array}{l}90 \\
95\end{array}$ & $\begin{array}{l}82 \\
93\end{array}$ & $\begin{array}{l}15.6 \\
16.2\end{array}$ \\
\hline Putnam et al. (1997) & $\begin{array}{l}376 \\
423 \\
388 \\
414\end{array}$ & $\begin{array}{l}138 \\
161 \\
165 \\
182\end{array}$ & $\begin{array}{l}18.1 \\
19.2 \\
18.3 \\
19\end{array}$ \\
\hline Robinson and Sniffen (1985) & $\begin{array}{l}119 \\
122 \\
137\end{array}$ & $\begin{array}{r}131 \\
62 \\
125\end{array}$ & $\begin{array}{l}18 \\
17.3 \\
17.7\end{array}$ \\
\hline Robinson et al. (1985) & $\begin{array}{r}33 \\
88 \\
120 \\
132\end{array}$ & $\begin{array}{r}13 \\
9 \\
88 \\
136\end{array}$ & $\begin{array}{r}6.4 \\
11.3 \\
15.8 \\
18.6\end{array}$ \\
\hline Rode et al. (1985) & $\begin{array}{r}157 \\
124 \\
194 \\
82 \\
91 \\
100 \\
91\end{array}$ & $\begin{array}{r}62 \\
44 \\
60 \\
124 \\
131 \\
103 \\
59\end{array}$ & $\begin{array}{l}14.3 \\
13.5 \\
14.3 \\
16.8 \\
17.7 \\
16.5 \\
14\end{array}$ \\
\hline Rooke et al. (1985) & $\begin{array}{l}16 \\
23 \\
39 \\
60\end{array}$ & $\begin{array}{l}3 \\
3 \\
9 \\
9\end{array}$ & $\begin{array}{l}3.3 \\
3.3 \\
6.2 \\
6.2\end{array}$ \\
\hline Shabi et al. (1998) & $\begin{array}{l}208 \\
272 \\
176 \\
240\end{array}$ & $\begin{array}{r}103 \\
112 \\
84 \\
109\end{array}$ & $\begin{array}{l}16.7 \\
16.4 \\
15.5 \\
16.1\end{array}$ \\
\hline Song and Kennelly (1989) & $\begin{array}{l}239 \\
242 \\
225\end{array}$ & $\begin{array}{l}50 \\
59 \\
48\end{array}$ & $\begin{array}{l}15.3 \\
15.8 \\
15.3\end{array}$ \\
\hline Stern et al. (1983) & $\begin{array}{l}208 \\
229 \\
299 \\
336\end{array}$ & $\begin{array}{r}86 \\
129 \\
167 \\
183\end{array}$ & $\begin{array}{l}17.6 \\
17.9 \\
17.8 \\
17\end{array}$ \\
\hline Tamminga et al. (1979) & $\begin{array}{r}66 \\
74 \\
64 \\
165 \\
200 \\
199\end{array}$ & $\begin{array}{r}15 \\
25 \\
34 \\
43 \\
72 \\
100\end{array}$ & $\begin{array}{r}8.2 \\
8.2 \\
8.2 \\
12.9 \\
12.9 \\
12.9\end{array}$ \\
\hline Tesfa (1993) & $\begin{array}{l}57 \\
56\end{array}$ & $\begin{array}{l}13 \\
14\end{array}$ & $\begin{array}{l}7.4 \\
7.9\end{array}$ \\
\hline
\end{tabular}

\footnotetext{
${ }^{1}$ NANMN $=$ Nonammonia nonmicrobial $\mathrm{N}$.

${ }^{2}$ Predicted values were derived using eq $5: \mathrm{RUP}_{\mathrm{adj} 2}=$ $100-$ NPN

$1+e^{-\left(\frac{\text { DMI }-c}{7.18}\right)}$
}

Table A2. Data set used to evaluate prediction equation 5.

\begin{tabular}{|c|c|c|c|}
\hline Reference & $\begin{array}{l}\text { Measured } \\
\text { NANMN }^{1}\end{array}$ & $\begin{array}{l}\text { Predicted } \\
\text { NANMN }^{2}\end{array}$ & DMI \\
\hline & \multicolumn{2}{|c|}{$(\mathrm{g} / \mathrm{d})$} & $(\mathrm{kg} / \mathrm{d})$ \\
\hline Ahvenjarvi et al. (2002) & $\begin{array}{l}133 \\
121 \\
164 \\
149\end{array}$ & $\begin{array}{l}25 \\
63 \\
59 \\
94\end{array}$ & $\begin{array}{l}13.8 \\
17.5 \\
16.2 \\
18.1\end{array}$ \\
\hline Callison et al. (2001) & $\begin{array}{l}189 \\
224 \\
229 \\
203 \\
211\end{array}$ & $\begin{array}{l}125 \\
131 \\
133 \\
119 \\
119\end{array}$ & $\begin{array}{l}18.4 \\
18.7 \\
18.8 \\
18 \\
18\end{array}$ \\
\hline Choi et al. (2002) & $\begin{array}{l}133 \\
120 \\
163 \\
148\end{array}$ & $\begin{array}{l}61 \\
25 \\
57 \\
92\end{array}$ & $\begin{array}{l}13.8 \\
17.5 \\
16.2 \\
18.1\end{array}$ \\
\hline Crocker et al. (1998) & $\begin{array}{l}249 \\
266 \\
261 \\
276\end{array}$ & $\begin{array}{l}110 \\
136 \\
133 \\
119\end{array}$ & $\begin{array}{l}17.7 \\
19.1 \\
18.9 \\
18.1\end{array}$ \\
\hline Elizalde et al. (1999) & $\begin{array}{l}51 \\
30 \\
35 \\
59 \\
67\end{array}$ & $\begin{array}{l}16 \\
26 \\
28 \\
28 \\
24\end{array}$ & $\begin{array}{l}8.5 \\
6.6 \\
8.7 \\
9.2 \\
9.3\end{array}$ \\
\hline Hamali et al. (2001a) & $\begin{array}{l}70 \\
66 \\
42 \\
39\end{array}$ & $\begin{array}{l}15 \\
14 \\
12 \\
11\end{array}$ & $\begin{array}{l}7.9 \\
7.7 \\
7.8 \\
7.6\end{array}$ \\
\hline Hamali et al. (2001b) & $\begin{array}{l}54 \\
54 \\
53\end{array}$ & $\begin{array}{l}10 \\
10 \\
11\end{array}$ & $\begin{array}{l}6.5 \\
6.5 \\
6.8\end{array}$ \\
\hline Ipharraguerre et al. (2002) & $\begin{array}{l}250 \\
265 \\
285 \\
275 \\
273\end{array}$ & $\begin{array}{l}210 \\
183 \\
195 \\
201 \\
172\end{array}$ & $\begin{array}{l}22.1 \\
21.1 \\
21.7 \\
22 \\
20.9\end{array}$ \\
\hline Oba and Allen (2003) & $\begin{array}{l}138 \\
123 \\
164 \\
191\end{array}$ & $\begin{array}{l}255 \\
330 \\
226 \\
228\end{array}$ & $\begin{array}{l}20.8 \\
22.5 \\
19.7 \\
19.6\end{array}$ \\
\hline Oldick and Firkins (2000) & $\begin{array}{l}65 \\
61 \\
58 \\
57\end{array}$ & $\begin{array}{l}13 \\
13 \\
13 \\
13\end{array}$ & $\begin{array}{l}8.5 \\
8.5 \\
8.5 \\
8.5\end{array}$ \\
\hline O’Mara et al. (1998) & $\begin{array}{r}61 \\
89 \\
104 \\
119\end{array}$ & $\begin{array}{l}24 \\
26 \\
47 \\
53\end{array}$ & $\begin{array}{l}10.9 \\
11.1 \\
13.2 \\
13.3\end{array}$ \\
\hline $\begin{array}{l}\text { Shabi et al. (personal } \\
\text { communication, 2003) }\end{array}$ & $\begin{array}{l}191 \\
256 \\
280 \\
277\end{array}$ & $\begin{array}{l}211 \\
241 \\
236 \\
190\end{array}$ & $\begin{array}{l}22.5 \\
23.6 \\
23.3 \\
21.3\end{array}$ \\
\hline Volden (1999) & $\begin{array}{r}218 \\
191 \\
169 \\
129 \\
116 \\
97\end{array}$ & $\begin{array}{r}97 \\
97 \\
53 \\
19 \\
19 \\
3\end{array}$ & $\begin{array}{r}19.3 \\
19.3 \\
19.3 \\
9.8 \\
9.8 \\
9.8\end{array}$ \\
\hline
\end{tabular}

\footnotetext{
${ }^{1}$ NANMN = Nonammonia nonmicrobial $\mathrm{N}$.

${ }^{2}$ Predicted values were derived using eq. 5: $\mathrm{RUP}_{\mathrm{adj} 2}=$ $\frac{100-\mathrm{NPN}}{1+e^{-\left(\frac{\mathrm{DMI}-c}{7.18}\right)}}$ 